\author{
Manizha Paktin', Adilova Dinar ${ }^{2}$ \\ ${ }^{1} \mathrm{PhD}$ researcher of the «International Educational Corporation», \\ ${ }^{2}$ Supervisor Prof. «International Educational Corporation», \\ ${ }^{1,2}$ Almaty, Republic of Kazakhstan
}

\title{
HOUSING ANALYSIS AND ECONOMIC DEVELOPMENT
}

Annotation. This article discusses the important goals of engineering economics in the construction industry and it can be said that this is the meaning of engineering economics in project control.

Keywords: Input resources, saving cost, construction costs goals of engineering economics in the construction industry.

Abstract: In general, the purpose of engineering application in construction and civil engineering projects is to achieve the final and most desirable result for each part of the input resources, saving cost and reasonable cost by using the correct execution methods and careful planning to achieve the goals.

Considering and presenting appropriate solutions and creating quality and reducing construction costs and increasing the added value of investment for investors, especially mass builders, is one of the important goals of engineering economics in the construction industry and it can be said that this is the meaning of engineering economics in engineering economics Project control is an effective factor that is a process to maintain the project path to achieve a justified economic balance between the three factors of time cost and quality during project implementation, which uses its own tools and techniques to do this important. The plan has been developed for the project so that when leaving this plan, by identifying the causes and planning the most economical and appropriate activities, the construction project can be placed in the closest and most optimal condition possible and in its main direction. If an organization is facing the challenges of a changing world, it must be prepared to change anything other than its core values. The only valuable foundation in an organization should be the core philosophy of doing business. In fact, the future of all businesses depends on the ups and downs of the economic cycle.

Market-based economies are always faced with periods of recession and boom, so recognizing the periods of boom and bust (periodic) in macroeconomics to adopt optimal policies is one of the important issues in economics. Preventing further losses in times of recession is crucial, and what changes can be made at this time to maximize preparedness for the organization and its projects. Emphasizes a range of internal and external issues that seriously threaten an organization's reputation and profitability. Managers try to use crisis management findings and integrate them with the achievements of strategic management and control systems management avoiding dangerous waves of unexpected events the downturns during the recession are dangerous for construction companies with inflexible structures and high fixed costs, and companies with inflexible employment contracts that invest heavily in their machinery and equipment. Is considered this study, after examining and recognizing the factors that 
affect the economic downturn in small organizations, figure1 presents a proposed model for the survival of construction industry contractors during the downturn.

As mentioned above, the abundance of supply able land is the first prerequisite for housing development. It is true that in the case of consumer goods, the pricing rule is subject to the law of supply and demand, but the supply and demand of ready-made land for construction is very different from the supply and demand of other goods, both consumer and capital. As different goods have different status in this regard. Land suitable for buildings and housing, which should be considered a capital good, is not only not prone to corruption, but unlike most other goods, it is not subject to theft, maintenance and repair costs, and the landowner can safely look at it for years. has it. Therefore, its supply must be much more than demand so that its price does not rise rapidly. Therefore, land policy should be done in such a way that there is never a shortage in the supply of land prepared for construction and housing [1].

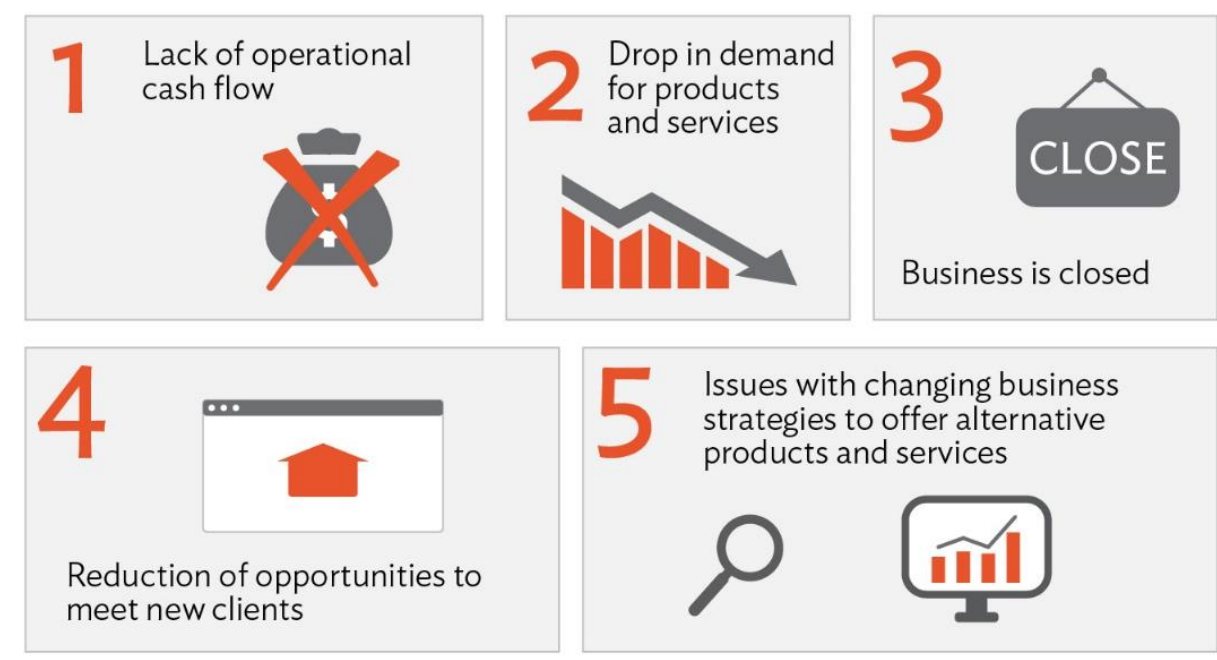

MSMEs also find difficulties obtaining raw materials, providing logistics and shipping of products. Workers are also not able to return to work.

Figure 1 - Models for the survival of construction industry contractors during the downturn

Housing investment, whether through the purchase of housing units or rent, accounts for a significant share of household income and savings. On the other hand, housing also plays an important role in public budgets. Also, building housing by creating a set of positive economic effects is a tool to reduce poverty. As shown in (Figure 2), investing in the housing sector without proper policy tools can increase inflation and put pressure on the balance of payments, which in turn have negative economic consequences as can be seen in (Figure 2), the relationship between the housing sector and the economy is complex and complex another point is that the level of resources allocated to the housing sector and the role given to it in different regions and countries are different. Housing investment is influenced by factors such as demand, economic models used, rate of development and others. 


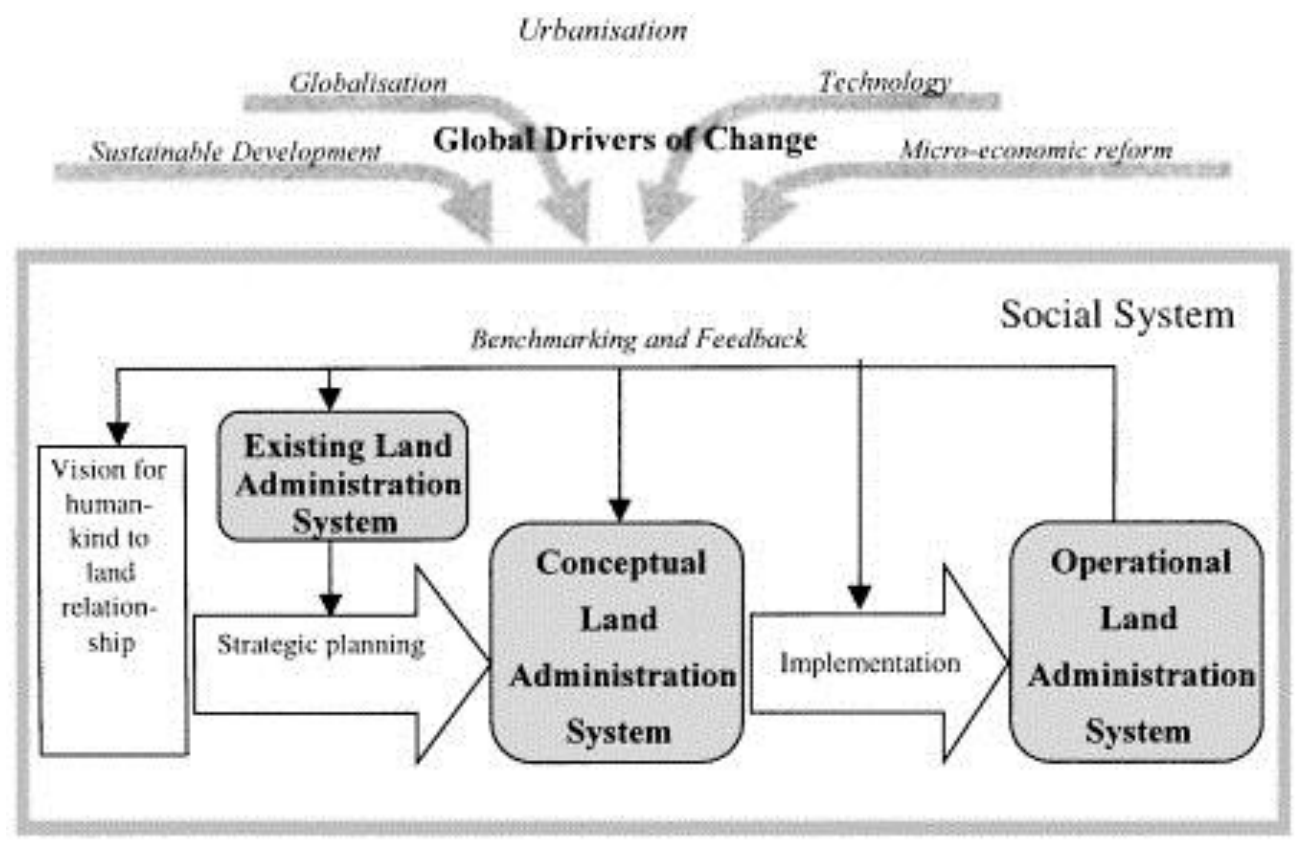

Figure 2 - The relationship between the housing sector and the economy is complex and complex

In the following, the relationship between housing and the economy will be further examined.

The role of all economic sectors is strong and weak, but the role of the housing economy in this area is considered from four key and pivotal perspectives.

1. The housing sector accounts for about $20 \%$ of GDP and more than $40 \%$ of GDP during the production and operation period. In addition, the wide demand for housing and its dependence on domestic inputs and the encouragement of endogenous and balanced growth patterns play a key role in achieving economic goals. The importance of this sector will be doubled if indirect effects and extensive connections with economic sectors are considered. Therefore, encouraging the production and investment of housing with the aim of providing shelter and acquiring housing assets without commercial motivation can play a pivotal role in economic growth.

2. It is impossible to curb inflation without considering the housing economy and the scientific and experimental knowledge of the performance of this sector. Housing during the period of non-severe shock alone is 5 to $7.5 \%$ of the cause of inflation. Assuming control of inflation in other sectors of the economy, failure to control housing shocks makes it impossible to achieve government goals and development plans and the vision document, because housing price shocks increase rents with a time lag that in turn exacerbates inflation. It should be noted that part of the government's success in reducing inflation is related to stopping the rise in housing prices, which usually occurs after the increase in housing price shocks.

3. Housing accounts for a significant share of the total household budget. Reducing the cost of living costs for households, especially low-income households and young people, who account for more than 50 percent of their income, should be a policy concern. Preventing the formation of rent and bargaining opportunities in the housing market, while stabilizing the housing market and helping to provide housing for the target groups, significantly reduces the incidental incomes of the limited groups 
and reduces the class gap and income gap. Controlling housing market shocks will therefore complement government subsidies and tax measures to improve income distribution and reduce class gaps.

4. The prevention of price shocks and the stabilization of the housing market provide a key and pivotal role in the optimal allocation of resources between the productive and service sectors and the financial market. Establishing a normal and acceptable return on housing production and investment will lead to the optimal allocation of resources in the housing sector throughout the country and the transfer of capital to the production, industrial and service sectors and will prevent less and more investment in the housing sector in business cycles. This is considered to be the most basic principle in achieving the goals of the resistance economy, and without considering it, the country's economic challenges will more or less continue. There is no incentive for economic activity when the purchase and sale of a residential unit generates several times the annual profit of a manufacturing or service enterprise. Therefore, while identifying and encouraging strategies to increase production and investment incentives in the economic sectors, it is necessary to prevent opportunities for accidental profit in housing trading and transfer capital to economic activities and the capital market, which itself encourages production and employment has it.

The need for housing varies in different countries and regions, and paying attention to providing adequate housing for people in the community plays a very important role in economic development. Another important factor that affects housing investment is the different development models used by countries at different times. The development model used will affect not only the amount of investment in the housing sector, but also the role given to it [2].

Also, the amount of resources allocated to the housing sector will be different at different stages of economic development. Also, growth rate and population composition significantly affect the amount of investment in the housing sector.

\section{Important Documents For Property Buying}

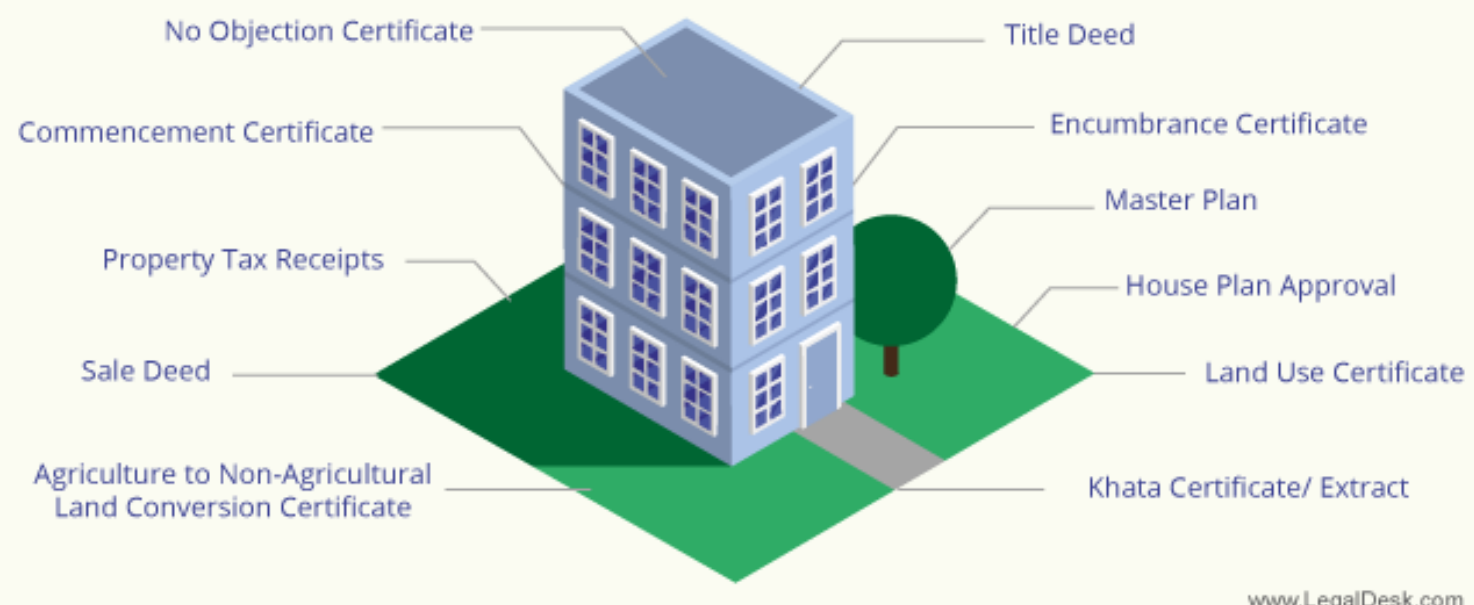

Figure 3 - 11 Important Documents for property buying 
The amount and sources of housing financing vary in centrally planned countries and market-based economies. In centrally planned economies, housing is viewed as a public good and is funded by the government. In this type of countries. In such a system, investing in housing is seen as a cost that has no return, and financial allocations pursue social and political goals rather than economic ones. Unlike centrally planned countries, in market-based economies, housing is an important part of economic development and growth, and the housing market is balanced by market mechanisms rather than by government the commercialization and privatization are important principles of the market mechanism the housing market has a greater ability to attract financial resources than a centrally planned economic system. Also, surveys of countries in transition have shifted from a centralized planning system to a marketbased system, indicating a significant increase in their domestic and foreign capital, because both the supply and demand of housing units require significant financial resources, individuals are unable to build or purchase on their own. In this case, it is necessary to connect the sector as a chain, the two parts of free financial resources and those involved in the housing sector. This is the task at hand for many financial institutions. Obviously, these institutions play a very important role in determining the amount of investment in housing, housing ownership and housing consumption. Among these institutions, we can mention banks and credit institutions.

Table 1 - Factors that housing market is effects on economic growth and development Major intervention Adjustment Retrenchment

\begin{tabular}{|c|c|c|}
\hline $\begin{array}{l}\text { Re/building a modern housing } \\
\text { stock }\end{array}$ & $\begin{array}{l}\text { Greater democratisation and } \\
\text { political contestation as } \\
\text { policy influences }\end{array}$ & $\begin{array}{l}\text { Mature housing system } \\
\text { characterised by majority } \\
\text { urban homeownership }\end{array}$ \\
\hline $\begin{array}{l}\text { Construction and housing- } \\
\text { related consumption drive } \\
\text { urban development and } \\
\text { economic growth }\end{array}$ & $\begin{array}{l}\text { Building up of other forms of } \\
\text { public and social provision } \\
\text { other than housing }\end{array}$ & $\begin{array}{l}\text { Greater internal political } \\
\text { contestation or pressures on } \\
\text { state legitimacy }\end{array}$ \\
\hline $\begin{array}{l}\text { Restructuring the housing } \\
\text { system: in the short term } \\
\text { around renting and } \\
\text { homeownership - in the long } \\
\text { term homeownership }\end{array}$ & $\begin{array}{l}\text { Adjustments to the housing } \\
\text { system to meet changing } \\
\text { social and economic } \\
\text { conditions: compensate for } \\
\text { market distortions }\end{array}$ & $\begin{array}{l}\text { Greater external influence of the } \\
\text { global economy and pressure } \\
\text { to become more competitive } \\
\text { and neo-liberal }\end{array}$ \\
\hline
\end{tabular}

As shown Table 1, the housing market is affected by a number of factors. However, the housing market has strong economic effects on economic growth and development. In this regard, it can be argued that housing is a kind of investment: costs are imposed over periods of several months to produce a stream of services that will be used for decades. The question is what effect these types of investments and the resulting flow of services will have on the economy. Research shows that the housing sector plays an important role in improving the economy from recession to prosperity. In the following, the positive and negative effects of investment in the housing sector on the national economy are examined [3]. 
As shown in Table 1, the housing market has direct effects on job creation and labor productivity, economic growth, income, savings, regional development, and economic reform.

Residential construction activities directly and indirectly create employment. Construction of housing units by employing a group of skilled and simple workers will create jobs in the area. Indirectly, the construction of housing units will create employment through a previous relationship with the industries that make construction materials and related products. Although housing construction is potentially a jobcreating factor, job creation and stimulating economic growth depend to a large extent on factors such as housing standards and the choice of technology.

In developing countries and in middle- and low-income residential areas, housing units are used not only as shelters, but also as the dominant source of household income through home-based enterprises. In developing countries, such activities make a significant contribution to national income and urban economic growth.

Creating adequate housing is also essential to increasing labor productivity. In other words, building housing units suitable for workers promotes productivity. There is a direct relationship between the type of housing unit, children's health and education, all of which are directly related to productivity.

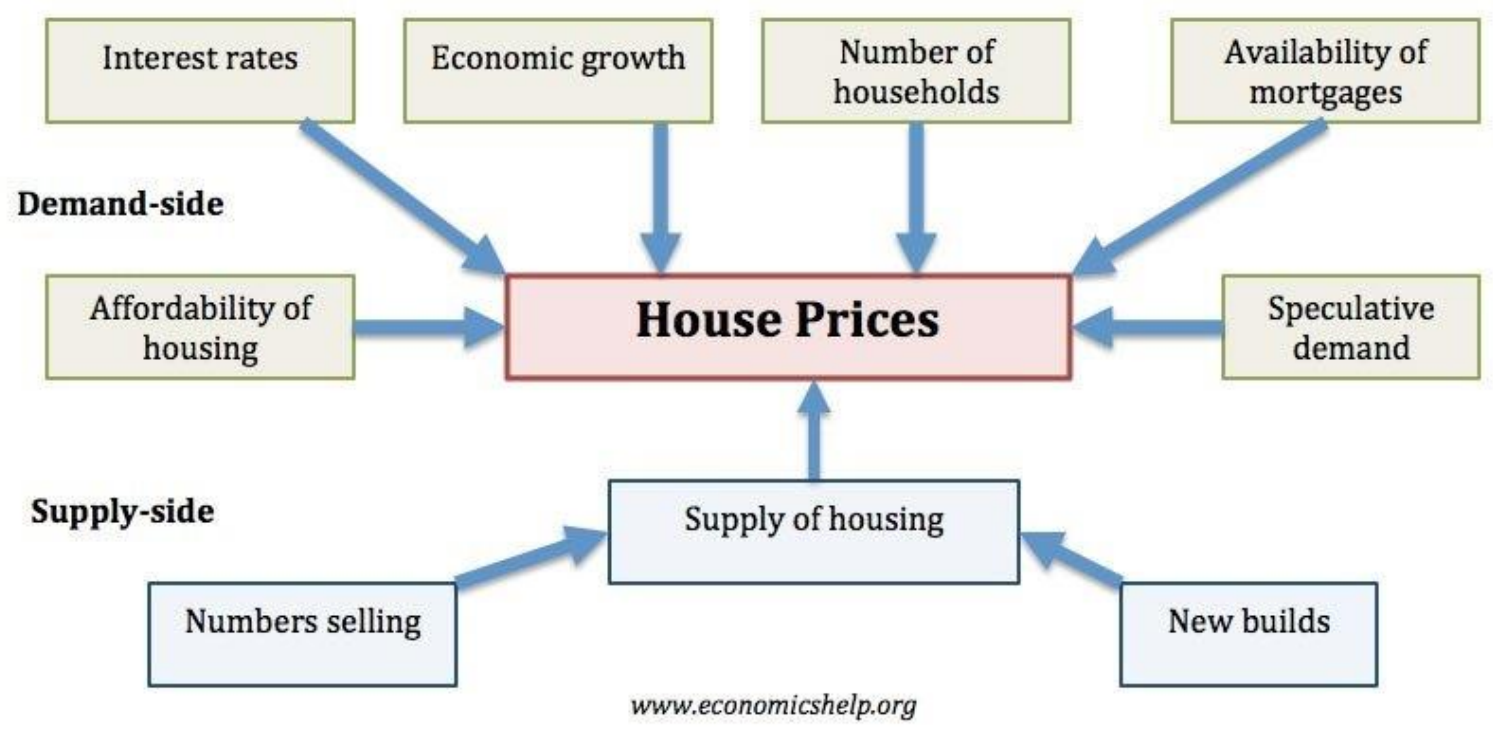

Figure 4 - Demand and supply side of house price

On the other hand, housing construction is one of the important economic activities that affects the whole economy. Housing has been proposed as a product that has added value as well as the formation of high gross fixed capital and also as a mediator for investment in other sectors and economic growth due to the lack of agreement on the causal direction between the housing sector and economic growth is a debate.

It is now widely accepted that the share of housing construction in economic growth varies from country to country. Richer countries often spend more on 
construction activities than poorer countries. As a result, value added in construction is higher in high-income countries than in low-income countries.

The role of housing becomes much more important and larger with regard to savings. The development of the housing financing system can be an important tool for shifting financial resources for the development of the domestic economy. Due to low incomes and lack of cohesive financial institutions, savings rates are low in most developing countries. These conditions force households to keep their savings on lowproductivity assets such as gold and jewelry. At the same time, many people have a strong desire to own a home. Owning a home is one of the highest priorities for most people in developing countries, and many are willing to forgo other areas in order to buy a home. If these household assets (which are not well used) were efficiently relocated and properly channeled, they could be used as a tool to develop the housing finance system and the domestic economy in general. The economic importance of housing is that the ownership of a housing unit is a valuable source of collateral and loans for business development. In addition, many activities in developing and developed countries are financed in this way. In addition to the direct effects, investment in the housing sector on the national economy, construction of housing units through previous links with industries supplying construction materials, has indirect positive effects on the economy. That is, an increase in construction activities will lead to an increase in the production of related industries and, as a result, will affect economic growth.

In addition to having positive effects, investing in housing can have negative effects such as inflation and balance of payments deficit:

In cases where a high proportion of the required building materials are imported from abroad, construction activities lead to a balance of payments deficit in the national economy. This is especially true for luxury housing units that have a high proportion of imported raw materials [4].

Huge government investment in the housing sector could drain resources from the production of export goods. On the other hand, most of the time the housing sector is not able to generate foreign exchange earnings. An increase in housing demand in the short term without a proportionate response from the supply side can affect housing prices, the prices of inputs used in housing, and the prices of goods and services. However, the impact of rising housing demand on prices depends on a number of factors, such as the elasticity of inputs and whether the increased demand is financed internally or externally. Targeted spending in the housing sector can lead to speculation in the real estate market and dramatically increase land prices.

\section{Resources:}

1. Green, $R$. Follow the leader: How changes in residential and non-residential investment predict changes in GDP// Journal of Finance. - 2017. - Vol. 51. - No 5. - P. 653-679.

2. Grimes O. F. Housing for Low-Income Urban Families. Economics and Policy in the Developing World// World Bank, Washington, D.C. - 2016. - Vol. 72. - No 3. - P. 172-213. 
3. Hirayama Y. Home-ownership in an unstable world, "Global construction set to rise, trillion by 2022, driven by Asia Pacific, Africa and the Middle East" // Building Design and Construction. 8 October 2018. Retrieved 29 April 2020.

4. McGraw-Hill Dictionary of Architecture and Construction, "Start of construction", accessed 8 September 2020, McCallum, D. and Stan, B. "Low income urban Housing in the Third World: Broadening the economic perspective" // Urban Studies. - Vol. 22. - P. 277-288.

В данной статье рассматриваются важные задачи инженерной экономики в строчтельной отрасли, и можно сказать, что именно в этом заключается смысл инженерной экономики в управлении проектами.

Ключевые слова: входные ресурсы, экономия затрат, затраты на строительство, цели инженерной экономики в строительной отрасли.

Бұл мақалада құрылыс индустриясындавы инженерлік экономиканың маңызыды мақсаттары талқыланады және бұл жобаны басқарудавы инженерлік экономиканың маңызы деп айтува болады.

Түйін сөздер: кіріс ресурстары, шывындарды үнемдеу, құрылыс шылындары, құрылысс индустриясындавы инженерлік экономика мақсаттары. 